\title{
Biodiversity of Pests in Grain Agrocenosis in Kabardino-Balkaria
}

\section{M Khromova1, A Kh Malkandueva², B R Shomakhov², Z L Shipsheva ${ }^{1}$, and A Kh Shabatukov ${ }^{1}$ \\ ${ }^{1}$ Plant Protection Laboratory, Institute of Agriculture of the Kabardino-Balkarian Research Center of the Russian Academy of Sciences, Nalchik, Russia \\ ${ }^{2}$ Laboratory of Grain Selection and Seed Production, Institute of Agriculture of the Kabardino- Balkarian Research Center of the Russian Academy of Sciences, Nalchik, Russia}

\section{Abstract}

The article studies the issues of resistance of winter wheat varieties selected by the State Center of grain n.a. P.P. Lukyanenko and the Institute of Agriculture of the KBRC of the RAS to pests. The studies were conducted in the steppe zone of Kabardino-Balkaria in the conditions of insufficient moisture in 2017-2018. Main diseases of winter wheat were identified, a valuable source material resistant to the main pathogens was isolated, and dominant diseases were established. The

Corresponding Author:

L M Khromova

kbniish2007@yandex.ru

Received: 25 October 2019

Accepted: 15 November 2019

Published: 25 November 2019

Publishing services provided by Knowledge E

(c) L M Khromova et al. This article is distributed under the terms of the Creative Commons

Attribution License, which permits unrestricted use and redistribution provided that the original author and source are credited.

Selection and Peer-review under the responsibility of the AgroSMART 2019 Conference Committee.

\section{G OPEN ACCESS} most adaptive, highly productive varieties of winter wheat were identified. The most ecologically plastic and stable varieties of winter wheat which can be used as donors were identified. Phytosanitary monitoring of the cotton moth was carried out in corn areas; phytophagous plants and the damage share were determined; progressive diseases were assessed; the species composition and frequency of pathogens were identified in grain areas.

Keywords: winter wheat, corn, selection, resistance, phytophagous phytopathogens, population size.

\section{Introduction}

The sharp change in the conditions and state of agricultural landscapes in modern environmental conditions caused new pathological connections. The economic importance of dominant pests depends on the soil and climatic conditions, crop rotation, ecological plasticity of winter wheat varieties and corn hybrids. It is necessary to implement effective protective measures to fight against harmful organisms.

Implementation of the improved system, integrated protection of winter wheat and corn against progressive phytophages and phytopathogens are relevant.

In 2017--2018, the species composition of pests was being studied. The degree of resistance of various varieties and hybrids to the conditions of the steppe zone of Kabardino-Balkaria was identified. 
The research aims to identify progressive pests that cause significant losses of grain yield. It is important to develop an environmentally-friendly system for integrated protection of winter wheat and corn.

\section{Purpose, Tasks and Novelty}

The purpose was to study the species diversity of phytophages in wheat and corn agrocenoses in the conditions of the steppe arid zone of the Kabardino-Balkarian Republic in order to develop and implement effective protective measures.

The following tasks were solved:

1. to determine the species composition of pests for experimental grain crops and study their harmfulness;

2. to identify the influence of abiotic factors on the resistance to pests;

3. to study the dynamics of the population of the cotton shovel in corn areas over the past 20 years.

The research novelty is due to the fact that for the first time in the arid steppe zone of the Kabardino-Balkarian Republic, comparative assessment of resistance winter wheat and corn hybrids to progressive phytophages and pathogens was carried out. The dynamics of the number of cotton moths was studied. The frequency of outbreaks of this dangerous pest in corn areas was analyzed.

\section{Methods and Materials}

Field experiments were carried out by existing methods [1--3]. For identification of phytophages and phytopathogens, pest determinants of agricultural crops were used $[4,5]$.

Research and production tests were carried out on 18 varieties of winter wheat and Terek F1 (FAO -- 400) corn hybrid.

The soil of experimental plots is southern black soils located between ordinary chernozem and dark chestnut soils. Southern black soil is characterized by an insignificant humus content in horizon A (3.5--5.0\%) and gradual distribution along the soil profile. These soils are intensively used for cultivation of spike crops, sunflower and corn [6].

Soil cultivation for Terek F1 hybrid included autumn plowing, spring cultivation and pre-sowing treatment. Corn was sowed with a seeding rate of 55 thousand seeds / ha 
in the first decade of May. Grain was sowed in the phase of full ripeness. Technological methods for keeping crops were based on the generally accepted system of cultivation of winter wheat and corn.

Phytosanitary monitoring of the dynamics of pests was carried out every decade. The amount of preserved yield ( $\mathrm{t}$ / ha) of the varieties of winter wheat and Terek F1 was determined.

An Infrascan-1050 infrared analyzer, OHAUS analytical scales, laboratory sieves, a Kjeldahl apparatus, IDK-3M, VLKT-500 technical scales, a moisture meter, magnifying glasses, Olympus and Biolam microscopes, portable entomological nets were used.

\section{Discussion}

It is impossible to control the number of populations of microorganisms without the use of resistant varieties and hybrids. It is discussed how to apply nanopesticides which have good wettability of the treated surface, an increased ability to penetrate into plant tissues and the speed of exposure to harmful organisms [7]. Purposeful selection of donors and sources of resistance plays an important role in improving integrated and group resistance of crops [8].

Plant protection is a priority factor in selecting immunological properties of plants resistant to the most dangerous species [9].

The determining element in the development of integrated protection of grain crops is monitoring $[10,11]$.

\section{Results}

Dominant disease were identified. They are as follows: Septoria tritici Blotch = Mycosphaerella graminicola, Erysiphe graminis DC.f.sp.tritici Em Marchal., Pyrenophora tritici-repentis (Died.) Drechsler, Puccinia striiformis West., Puccinia graminis f.sp. tritici, Alternarium, Cladosporium spp., Tilletia tritici (Bjerk) Wint..

In the areas of experimental crops of winter wheat varieties, septoria was observed in the fall and increased in spring. Cheget and Lebed were most affected by septoria. Of all the above-mentioned diseases, the causative agent of pyrenoforosis which was manifested on the leaves of all the varieties, turned out to be the most significant by its harmfulness. Pyrenoforosis in the phenophase "flag leaf" was observed in the following varieties: Yuzhanka, Bezostaya 100, Cheget, Alievich, Svarog, Step and Veha. 
In the period under study, rust diseases were in a depressed state. However, the weak spread of yellow rust was observed in Tanya, and single manifestations of stem rust were found in Grom. In general, harmfulness of phytopathogens has been relatively low. In 2018, the climatic conditions of the spring-summer period were very favorable for manifestation of solid smut on separate spikelets in the form of smut sacks.

In autumn, low relative air humidity and minimal air temperature $\left(5--8{ }^{\circ} \mathrm{C}\right)$ caused infection of winter wheat varieties with the agent of covered smut. The assessment of severity of covered smut showed that Tanya, Cheget and Veha are more susceptible to this disease than Laureat, Yuzhanka, Step, Alekseich, Alievich, Grom, Lebed and Dolya (Table 1).

During the growing period, pyrenophorosis developed. Its causative agent can develop in a temperature range from 6 to $40{ }^{\circ} \mathrm{C}$. According to our observations, the optimal temperature for the spread and development of pyrenophorosis is $25--30{ }^{\circ} \mathrm{C}$. it was registered in 2017 and 2018. Yuzhanka, Pamyati Shatilova, Alievich, Svarog, Veha are resistant to pyrenophorosis. The maximum development of pyrenoforosis was observed in Cheget.

The steady high temperature $\left(35--40^{\circ} \mathrm{C}\right)$ during the period of mass flowering of winter wheat (the first and second decades of May) and a short-term increase in humidity due to the last rains during the milky ripeness period (the first decade of June), caused the spread of alternariosis and cladosporiosis in all the varieties of winter wheat.

Out of 18 varieties of winter wheat selected by the State research Center named after P.P. Lukyanenko and the Institute of Agriculture of the KBRC of the RAS, 5 varieties have high productivity: Alekseich, Pamyati Shatilova, Alievich, Cheget, Yuzhanka. The yield varied from 6.3 to 7.7 tons per hectare (Fig. 1).

Alekseich, a variety of winter wheat distinguished by a productivity of 7.7--13.2 t/ha. It forms agrophytocenoses with dense ears. The average yield of Pamyaty Shatilova variety was $7.0 \mathrm{t} / \mathrm{ha}$, but the potential of grain productivity was $10.0 \mathrm{t} / \mathrm{ha}$. The technological qualities of grain and flour are high: the protein and gluten content averaged 14.0 and $25.6 \%$. Alievich and Cheget varieties are resistant to frost and drought, and harmful diseases of winter wheat. The productivity potential is 9.0--11.0 t/ha. By the grain quality, they correspond to strong wheat, since the protein content is 14.0--16.0\%, and gluten content is 28.0--29.0\%. The yield of Yuzhank variety is 6.3--12.0 t/ha. It is characterized by high flour-baking qualities due to the high protein and gluten content and high drought-resistance. The variety is highly adaptable and is recommended for cultivation in different soil and climatic conditions of the North Caucasus. 
TABLE 1: Phytosanitary STATE of winter wheat crops of the Al of the KBRC, RAS (steppe zone of KabardinoBalkaria, 2017--2018).

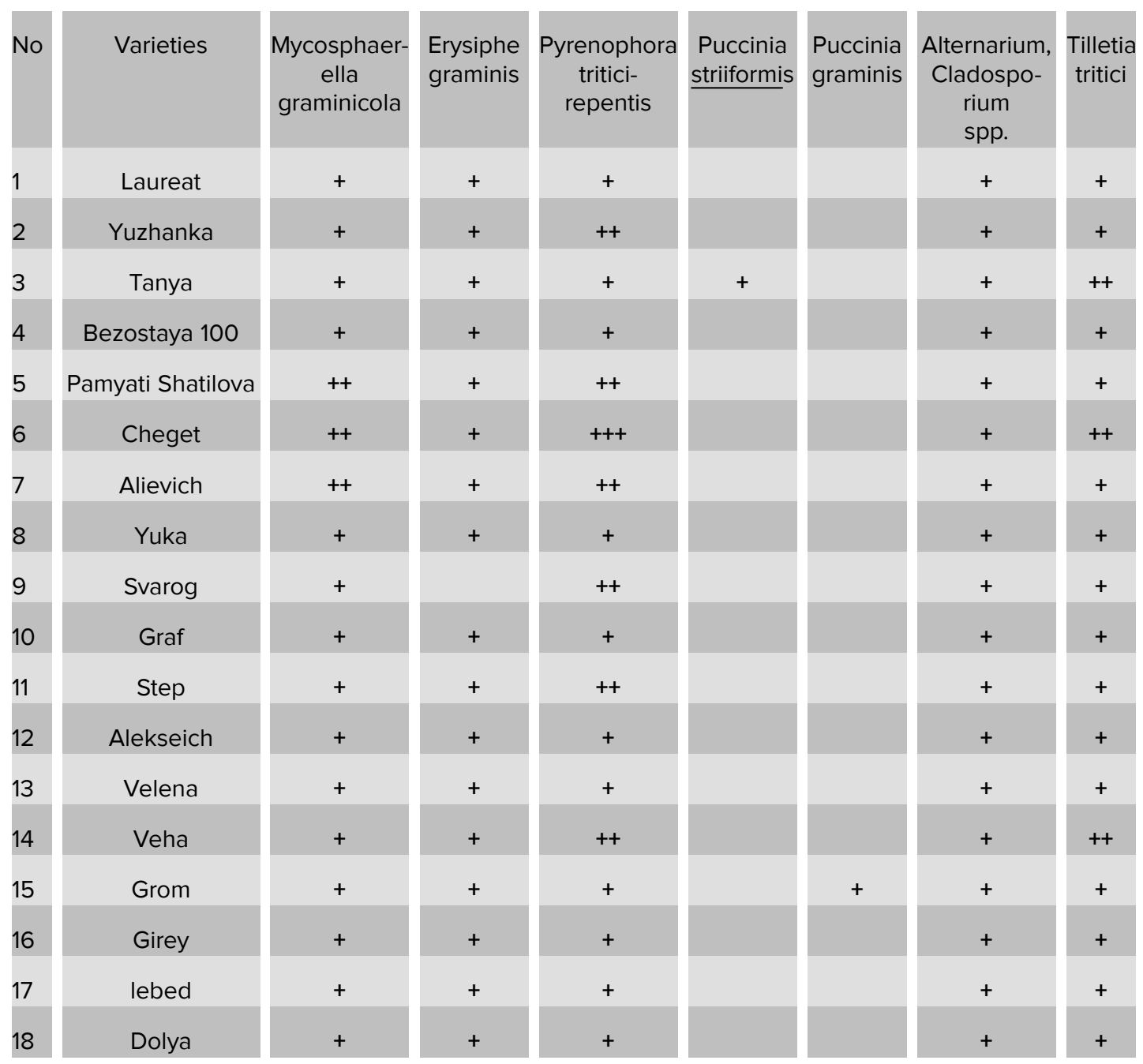

*Note: susceptibility to harmful diseases: + weak, ++ medium, +++ strong.

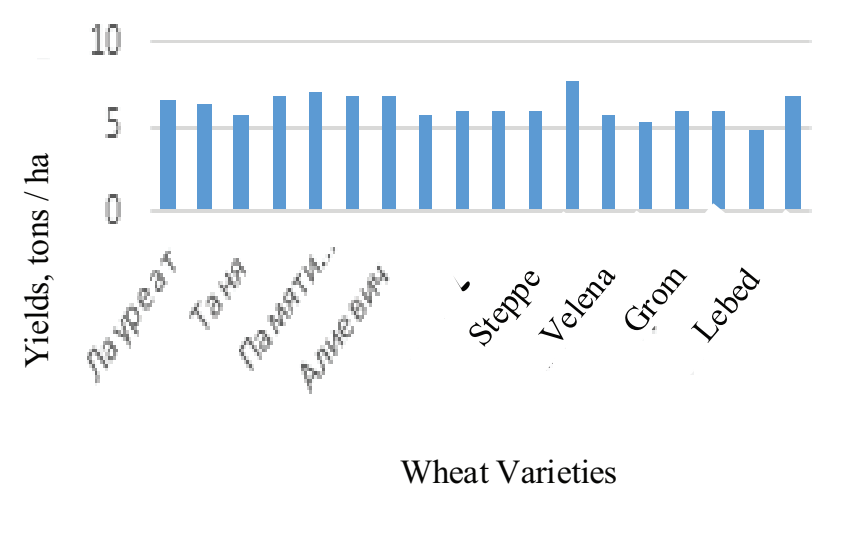

Figure 1: Comparative assessment of winter wheat varieties by economic efficiency (steppe zone of the KBR, 2017--2018). 
In the last 20 years, an increase in corn sowing areas in Kabardino-Balkaria and its short crop rotation increased the population and severity of the cotton shovel (Heliothis armigera HB.). The zero-soil freezing contributed to their pupal stage. Therefore, harmfulness of the cotton shovel larvae was significant, especially in 2018 and the share of damaged plants averaged $89.4 \%$, maximum $100 \%$. The population density was of 3.7 (maximum 8).

Phytosanitary monitoring of the dynamics of the cotton shovel was carried out on various corn hybrids in the steppe zone of the Kabardino-Balkarian Republic where the population density of the cotton shovel was high [12].

Certain phytophages in corn areas have an annual distribution, but their harmfulness depends on weather and climatic conditions, biochemical indicators of grain and green mass. The large population of exclamation scoops (Scotia exclamationis L.) and corn dung beetle (Pentodon idiota Hrbst.) was identified (Table 2). The peak of the population of the 2 nd generation cotton moth caterpillar was at intervals of 5--6 years (Fig. 2).

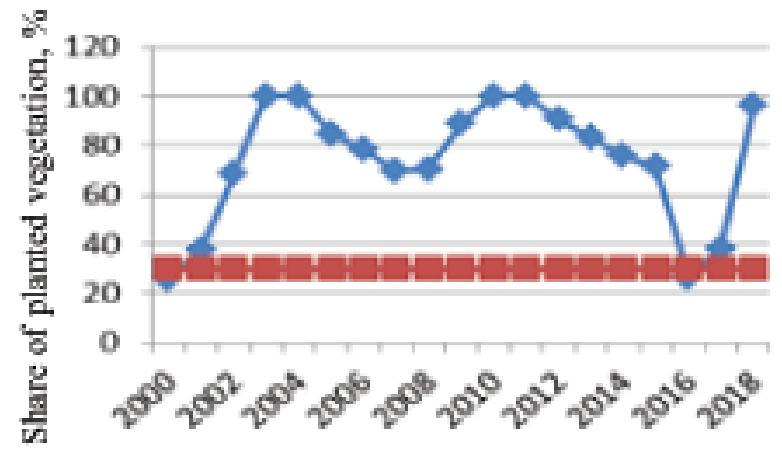

Figure 2: Dynamics of the number and harmfulness of the cotton shovel on corn crops in the steppe zone of the KBR, 2000--2018 (the red line is the economic threshold of harmfulness (30\% of damaged. plants), the blue line -- \% of damaged plants.

In some corn areas, discrepancy between the flowering period of panicles and cobs, and the cotton shovel reduced the yield.

It was established that during the corn growing season, the dominant diseases were Alternaria, blisters smut, pink fusarium rot and leaf blister burn. Severity of blistering smut is higher for stem, leaf and cob infections. In the experimental period, mainly the renal disease was recorded. Due to the late development of this disease, the share of damaged plants varied from 2 to $10 \%$. Other diseases with one "+" were not significant. In the cobs damaged by the cotton moth, dark mycelium of mold fungi developed. Graygreen mycelium of mold fungi whose causative agents is the Penicillium and Aspergillus was less widespread (Table 3). 
TABLE 2: Species composition and frequency of phytophages in corn areas (KBR steppe zone, 2017--2018).

\begin{tabular}{|c|c|c|}
\hline No & Name & $\begin{array}{l}\text { Weighted average } \\
\% \text { of damaged } \\
\text { plants }\end{array}$ \\
\hline 1 & $\begin{array}{l}\text { Click beettles } \\
\text { Agriotes sputator L. } \\
\text { Agriotes gurgistanus Fald. }\end{array}$ & + \\
\hline 2 & $\begin{array}{l}\text { Darkling beetles } \\
\text { Pedinus femoralis L. } \\
\text { Blaps halophila F. }\end{array}$ & + \\
\hline 3 & Pentodon idiota Hrbst. & ++ \\
\hline 4 & $\begin{array}{l}\text { Noctuidae: } \\
\text { Scotia segetum Schiff. } \\
\text { Autographa gamma L.= Phytometra gamma L.; } \\
\text { Scotia exclamationis L. }\end{array}$ & $\begin{array}{l}+ \\
+ \\
++\end{array}$ \\
\hline 5 & $\begin{array}{l}\text { Heliothis armigera } \mathrm{Hb}=\text { Helicoverpa armigera } \mathrm{Hb} \text {. } \\
\text { Chloridea armigera } \mathrm{Hb} \text {. }\end{array}$ & +++ \\
\hline 6 & $\begin{array}{l}\text {-Oscinella frit L. } \\
\text {-Oscinella pusilla Mg. }\end{array}$ & $\begin{array}{l}+ \\
+\end{array}$ \\
\hline 7 & Lema melanopus L. & + \\
\hline 8 & Pyrausta sticticalis L. & + \\
\hline 9 & Ostrinia nubilalis $\mathrm{Hb}$. & + \\
\hline 10 & Hyles livornica Esper. & + \\
\hline
\end{tabular}

* Note: + -- weak (0--10 \%); ++ -- average (10--30 \%); +++ -- strong (30--100\%).

TABLE 3: Species composition and frequency of phytopathogens in maize (steppe zone of the KBR, 2017-2018).

\begin{tabular}{|c|c|c|}
\hline No & Name & $\begin{array}{l}\text { Weighted average } \\
\% \text { of damaged } \\
\text { plants }\end{array}$ \\
\hline 1 & Fusarium moniforme Sheldon & + \\
\hline 2 & Ustilago maydis (Beckm.)Unger. =U.zeae Unger. & ++ \\
\hline 3 & Sorosporium reilianum McAlpine= Ustilago reilianum Kuhn. & -- \\
\hline 4 & Puccinia sorghi Schw.= P. maydis Ber. & -- \\
\hline 5 & $\begin{array}{l}\text { Helminthosporium turcicum Pass.= Drechslera turcicum Pass. } \\
\text { Helminthosporium maydis Lobik. = Drechslera maydis Lobik.; } \\
\text { Helminthosporium carbonum Ullstr.= Drechslera carbonum Ullstr. }\end{array}$ & $\begin{array}{l}-- \\
--\end{array}$ \\
\hline 6 & Alternarium spp. & ++ \\
\hline 7 & Colletotrichum zeae Lobik & + \\
\hline 8 & Fusarium graminearum Schw.= F. roseum Link. var.maidis Sacc. & ++ \\
\hline 9 & Fusarium graminearum Schwabe.; Gibberella zea(Schweinitz) Petch & + \\
\hline 10 & Rhizopus maydis Brud. & + \\
\hline 11 & Trichothecium roseum Link. & ++ \\
\hline 12 & Cladosporium herbarum Link. & ++ \\
\hline 13 & Sclerotatium bataticola Taub. & -- \\
\hline 14 & $\begin{array}{l}\text { Pseudomonas holci Kehdr) Berg.; } \\
\text { Erwinia dissolvens (Rosen) Burkh.; } \\
\text { Bacillus mesentericus-vulgatus Flugge. }\end{array}$ & $\begin{array}{l}++ \\
-- \\
--\end{array}$ \\
\hline
\end{tabular}

* Note: + -- weak (0--5 \%); ++ -- average (5--50 \%); +++ -- strong (50--100 \%). 

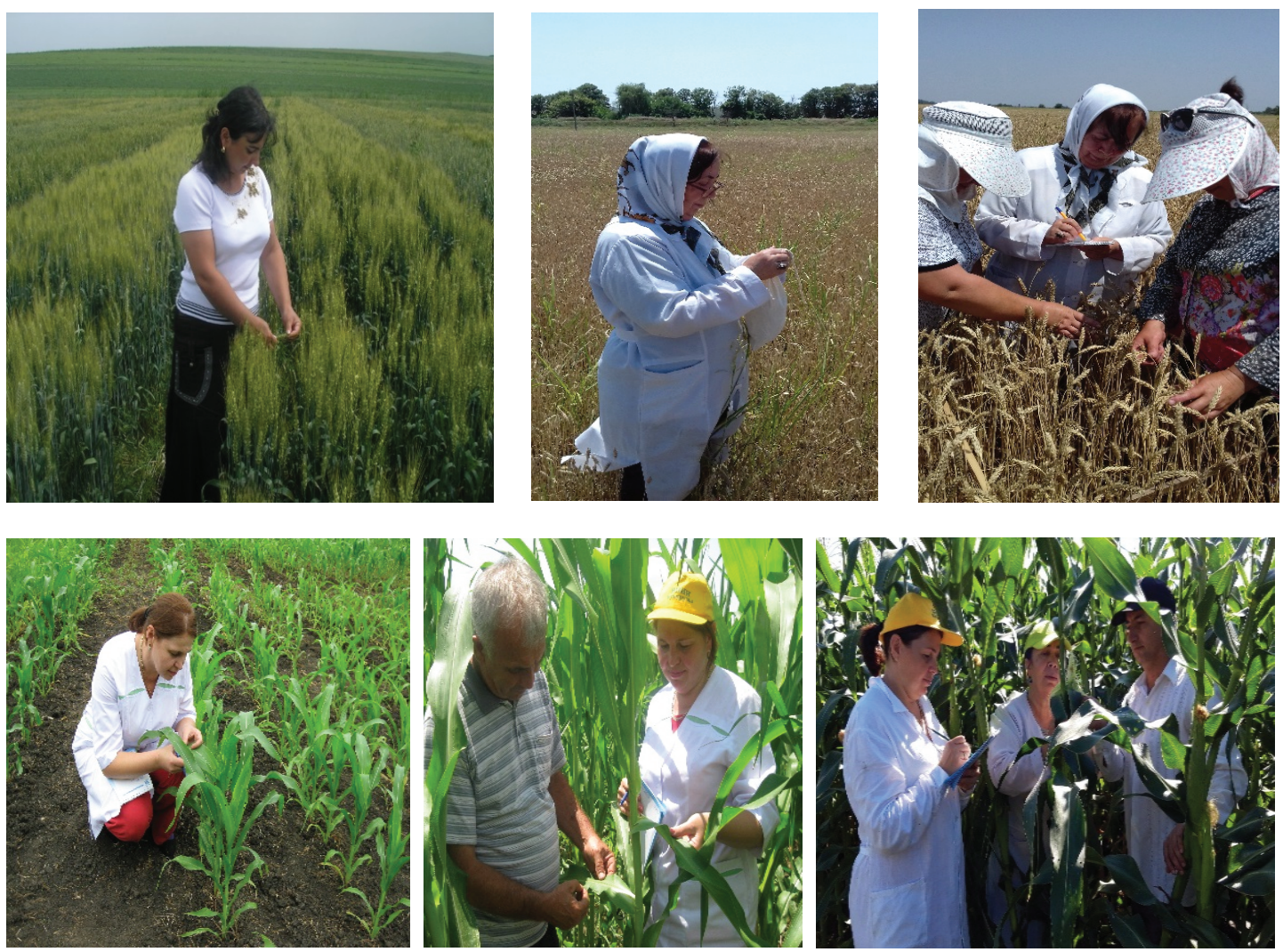

Figure 3: Monitoring of the condition of the winter wgeats.

In experimental corn areas, the first watering contributed to accumulation of pathogens of root and root rot of fungal and bacterial etiology. The subsequent watering had little effect on its development. During the growing period, decadal phytosanitary monitoring of pests was carried out; suspicious samples were identified in the laboratory conditions. The dependence of development of bubbly smut, mold fungi on the main predictors of weather and agrotechnical measures (watering, inter-row processing, etc.) was revealed.

\section{Conclusion}

Based on the research results, the following conclusions can be drawn:

1. the species composition of pests in winter wheat and corn areas in the steppe arid zone of the Kabardino-Balkarian Republic and dominant species were identified;

2. Alekseich, Alievich and Yuzhanka varieties have the most stable characteristics that determine the yield and quality of grain. They can be as donors as they have significant advantages in environmental plasticity compared to other varieties; 
3. the dynamics of the number and harmfulness of the cotton shovel over the past 20 years was studied. It was identified that the outbreak of the cotton shovel is observed each 5--6 years.

\section{References}

[1] Dospekhov, B.A. (1985). Methods of field experience. Moscow: Agropromizdat, 352 p.

[2] Peresypkin, V.F., Shelestova, S.S., Asatur, M.K. (1989). Workshop on the methodology of experimental work in plant protection. Moscow: Agropromizdat, pp. 17--20.

[3] Chumakov, A.I., Zakharova, T.I. (1990). Harmfulness of crop diseases. Moscow, pp. 18$-19$.

[4] Akhremevich, M.B., Batiashvili, I.D., Bey -- Bienko. (1976). Determinant of agricultural pests for damage to cultivated plants. Leningrad, pp. 38--48.

[5] Khokhryakov, M.K., Potlaychuk V.I. et al. (1984). Key to diseases of agricultural crops. Moscow, pp. 121--134.

[6] Ivanov, A.L., Molchanov, E.N., Chochaev, M.M. et al. Features of the adaptive -landscape system of agriculture of the Kabardino-Balkarian Republic. Nalchik, 2013, pp. 17--53.

[7] Woods, T.S. (1999). Product Firms for Modern Agriculture. The Food Environment. Royal Society of Chemistry, pp.121--153.

[8] Zakharenko, V.A. (2009). The tendency of development of nanofytosanitary in plant protection. Protection and quarantine of plants, vol. 5, pp. 13--17.

[9] Bespalova, L.A., Romanenko, A.A., Kolesnikov, F.A. (2018). Varieties of wheat and triticale Federal State Budgetary Scientific Institution. Krasnodar: NPTs im. P. Lukyanenko, $164 \mathrm{p}$.

[10] Edwards, H.H. (2002). Development of primary germ tubes by conidia of Blumeria graminis f.sp.hordei on leaf epidermal cells of Hordeum vulgare. Can. J. Bot., vol. 80, pp. 1121--1125.

[11] Vechet, L. (2003). Development of povdery mildew and red rust epidemics in winter wheat cultivars. Plant, Soil and Envirion, vol. 49, pp. 439--442.

[12] Pests of agricultural crops. Pests of grain crops, vol. I. Moscow: Printed City, 2012, pp. 344--347. 